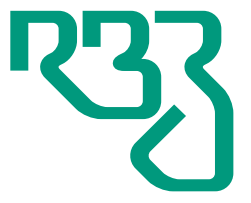

Revista Brasileira de Zootecnia

Brazilian Journal of Animal Science ISSN 1806-9290 www.rbz.org.br

\title{
Effects of antibiotic growth promoters mixed with mineral supplement on growth performance, ingestive behavior, and mineral intake of grazing bulls
}

\author{
Marcelo Vedovatto $^{1}$ iD, José Mauro da Silva Diogo ${ }^{2}$ iD, João Artêmio Marin \\ Beltrame $^{3}$ (iD, Marcella Cândia D’Oliveira ${ }^{3}$ (iD, Cássio José da Silva² (iD), \\ Clayton Quirino Mendes² (iD), Sergio Lucio Salomon Cabral Filho² (iD), \\ Gumercindo Loriano Franco ${ }^{3^{*}}$ iD \\ ${ }^{1}$ University of Florida, Range Cattle Research and Education Center, Ona, FL, USA. \\ ${ }^{2}$ Universidade de Brasília, Faculdade de Agronomia e Medicina Veterinária, Brasília, DF, Brasil. \\ ${ }^{3}$ Universidade Federal de Mato Grosso do Sul, Faculdade de Medicina Veterinária e \\ Zootecnia, Campo Grande, MS, Brasil.
}

\begin{abstract}
*Corresponding author: gumercindo.franco@ufms.br

Received: May 27, 2019

Accepted: June 14, 2019

How to cite: Vedovatto, M.; Diogo, J. M. S.; Beltrame, J. A. M.; D’Oliveira, M. C.; Silva, C. J Mendes, C. Q.; Cabral Filho, S. L. S. and Franco, G. L. 2019. Effects of antibiotic growth promoters mixed with mineral supplement on growth performance, ingestive behavior, and mineral intake of grazing bulls. Revista Brasileira de Zootecnia 48:e20190114.

https://doi.org/10.1590/rbz4820190114

Copyright: This is an open access article distributed under the terms of the Creative Commons Attribution License (http://creativecommons.org/licenses/by/4.0/), which permits unrestricted use, distribution, and reproduction in any medium, provided the original work is properly cited.
\end{abstract}

\begin{abstract}
The objective was to evaluate the addition of antibiotic growth promoters to free-choice mineral supplement on ingestive behavior, mineral intake, and growth performance of grazing bulls. Sixty Nellore bulls [initial body weight (BW) of $219 \pm 17.8 \mathrm{~kg}$ and $15 \pm 2$ months of age] were divided in 12 marandu grass paddocks. The treatments were: mineral supplement (control), mineral supplement + virginiamycin (VIRG), mineral supplement + lasalocid sodium (LASA) and mineral supplement + salinomycin sodium (SALI). Mineral supplements were formulated with target intake of $60 \mathrm{~g} \mathrm{~d}^{-1}$ and the growth promoters of $75 \mathrm{mg} 100 \mathrm{~kg}^{-1}$ of BW. The experimental design was the completely randomized blocks. There was no treatment effect on ingestive behavior or mineral intake; however, the active ingredient intake differed between treatments. In the last experimental period, the intake of active ingredient LASA and SALI were higher than VIRG $\left(0.66,0.54\right.$, and $0.39 \mathrm{mg} \mathrm{kg}^{-1}$ of BW, respectively). Treatments also did not affect BW and average daily gain, which were $0.63,0.60,0.64$, and $0.62 \mathrm{~kg} \mathrm{~d}^{-1}$ for control, VIRG, LASA, and SALI, respectively. Free-choice mineral supplementation intake by bulls has a high variability, and this impairs the regulation of the intake of antibiotic growth promoter additives. Therefore, the addition of antibiotic growth promoters to the mineral supplement does not affect ingestive behavior, mineral intake, and growth performance of grazing bulls.
\end{abstract}

Keywords: feed additive, cattle, ionophore, lasalocid, salinomycin, virginiamycin

\section{Introduction}

The free-choice mineral supplement is an alternative for the administration of antibiotic growth promoters that potentiate ruminal fermentation. Among several growth promoters, ionophores such as lasalocid and salinomycin sodium, and virginiamycin antibiotic, are noteworthy. They act mainly against gram-positive bacteria present in the rumen, improving ruminal fermentation efficiency (Page, 2003).

With the selection of gram-negative bacteria in the ruminal environment, under the same diet, animals produce more energy due to the increase of fermentative efficiency, mainly by the increase of propionate production, and reduce ammoniacal nitrogen production, which can generate improvements on feed efficiency, in addition to reducing the environmental impacts provoked by cattle production, since $\mathrm{CH}_{4}$ emission is also reduced (Page, 2003). Thus, the improvement in the efficiency of protein and energy 
utilization of the diet (Russel and Strobel, 1989; Page, 2003) may reflect in higher weight gain of grazing animals (Bretschneider et al., 2008).

The beneficial effects of using antibiotic growth promoters in feedlot or grazing cattle that consume concentrated supplementation have already been extensively proven (Bretschneider et al., 2008; Golder and Lean, 2016). However, the use of mineral supplement as a vehicle for supplying antibiotic growth promoters has been widely employed, but with few studies proving its beneficial effects (Rode et al., 1994).

We hypothesized that the addition of antibiotic growth promoters to mineral supplements will increase weight gain of bulls grazing on tropical pastures. Thus the objective of this study was to evaluate the addition of antibiotic growth promoters to the free-choice mineral supplement on growth performance, ingestive behavior, and mineral intake of grazing bulls.

\section{Material and Methods}

The study was conducted according to the institutional committee on animal use (case number 366/2011). The experiment was carried out from January 19 to May 10, 2012 (112 d) in the Distrito Federal, Brazil $\left(15^{\circ} 55^{\prime} 12.55^{\prime \prime}\right.$ south latitude and $47^{\circ} 55^{\prime} 12.55^{\prime \prime}$ west longitude, with altitude close to $1000 \mathrm{~m}$ ). According to the Köppen classification, the climate is Aw (tropical seasonal savanna) and is situated between tropical savanna and temperate rainy climate of dry winter, with an average rainfall of $1550 \mathrm{~mm}$ annually. The soil is classified as typical A-moderate Dystrophic Red-Yellow Latosol, with a very clayey texture, a tropical Cerrado sub-deciduous phase and flat relief (EMBRAPA, 1999). Rainfall and temperature variation during the experimental period were obtained from the farm automatic weather station (Figure 1).

The experimental area consisted of 12 paddocks with 2 ha each, formed with marandu grass pastures, Urochloa brizantha (Hochst. Ex A. Rich) R. D. Webster, cv. Marandu, [syn. Brachiaria brizantha (Hochst. Ex A. Rich) Stapf]. The paddocks had some native Cerrado vegetation that acted as shade to the animals. All paddocks had covered troughs for supplementation and drinking fountains with automatic replenishment.

We used 60 Nellore bulls of $15 \pm 2$ months of age, average body weight (BW) of $219 \pm 17.8 \mathrm{~kg}$, and numerically identified with auricular earring and marked with hot iron on the leg. Before the experiment,

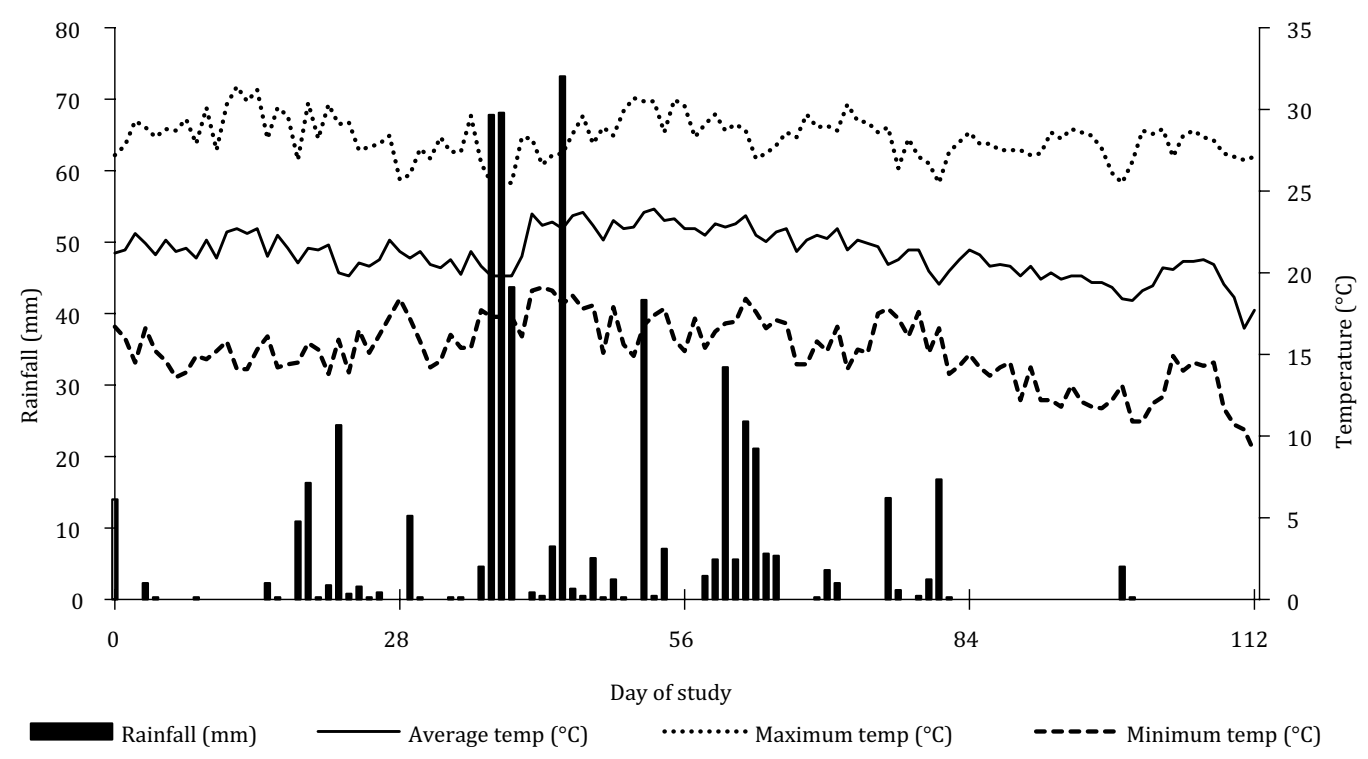

Figure 1 - Rainfall and average temperature during the experiment in Brasília, Distrito Federal, Brazil. 
the animals underwent $40 \mathrm{~d}$ of adaptation on the marandu grass pasture, receiving free-choice mineral supplementation without any antibiotic growth promoters. Mineral supplements were produced and packaged by a mineral supplementation company that added antibiotic growth promoters to a commercial formula (Table 1) to meet the mineral requirements of growing beef cattle with average daily gain (ADG) of $0.600 \mathrm{~kg} \mathrm{~d}^{-1}(\mathrm{NRC}, 1996)$ and the target intake of $60 \mathrm{~g} \mathrm{~d}^{-1}$.

The animals were divided into paddocks and subjected to one of four treatments: mineral supplement (control), mineral supplement + virginiamycin (VIRG), mineral supplement + lasalocid sodium (LASA), or mineral supplement + salinomycin sodium (SALI). For all treatments employing growth promoters,

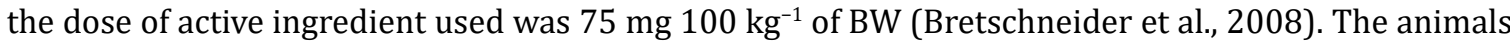
were randomly chosen and divided into 12 groups, and each group was considered an experimental unit, totaling three repetitions for each treatment, with five animals each. The groups were separated into three blocks composed by four paddocks, with one group of each treatment per block. Weekly group rotations in the paddocks were performed inside each block, aiming at removing possible paddock effects on weight gain.

At the beginning of the experiment $(\mathrm{d} 0)$, the animals were weighed individually after water and food fasting for $16 \mathrm{~h}$, and from this, weighing was repeated every $28 \mathrm{~d}$. The ADG of animals was calculated by the difference between the final weight and initial weight at each experimental period, divided by the number of days of the period.

The mineral supplement associated or not with antibiotic growth promoters was supplied ad libitum in troughs, which allowed simultaneous access for all animals. The troughs were visually evaluated every day and replenished whenever they presented approximately $1 \mathrm{~kg}$ of leftovers. Weekly control of the mineral supplement intake was done by subtracting the weight of leftovers, corrected for moisture content, with the total provided during the week. For moisture correction of leftovers, $100 \mathrm{~g}$ samples were harvested and dried in a forced-air ventilation oven at $65^{\circ} \mathrm{C}$ for $72 \mathrm{~h}$.

Forage harvests were carried out every $28 \mathrm{~d}$, simultaneously with the weighing of the animals, during the morning, therefore, without the presence of the animals in the paddocks. The evaluation of the forage mass was done using a $0.5 \mathrm{~m}^{2}$ metal square randomly placed at eight points within the paddock, and forage cutting was performed at $5 \mathrm{~cm}$ from the soil. The samples were weighed in the

Table 1 - Guaranteed levels of mineral supplement containing antibiotic growth promoters ${ }^{1}$

\begin{tabular}{|c|c|c|c|c|}
\hline \multirow{2}{*}{ Component } & \multicolumn{4}{|c|}{ Treatment $^{2}$} \\
\hline & Control & VIRG & LASA & SALI \\
\hline Calcium $\left(\mathrm{g} \mathrm{kg}^{-1}\right)$ & 194 & 184 & 187 & 185 \\
\hline Sulfur $\left(\mathrm{g} \mathrm{kg}^{-1}\right)$ & 16 & 16 & 16 & 16 \\
\hline Phosphorus ( $\mathrm{g} \mathrm{kg}^{-1}$ ) & 70 & 70 & 70 & 70 \\
\hline Sodium $\left(\mathrm{g} \mathrm{kg}^{-1}\right)$ & 109 & 109 & 109 & 109 \\
\hline Cobalt $\left(\mathrm{mg} \mathrm{kg}^{-1}\right)$ & 50 & 50 & 50 & 50 \\
\hline Copper $\left(\mathrm{mg} \mathrm{kg}^{-1}\right)$ & 1050 & 1050 & 1050 & 1050 \\
\hline Iodine $\left(\mathrm{mg} \mathrm{kg}^{-1}\right)$ & 60 & 60 & 60 & 60 \\
\hline Manganese $\left(\mathrm{mg} \mathrm{kg}^{-1}\right)$ & 900 & 900 & 900 & 900 \\
\hline Selenium $\left(\mathrm{mg} \mathrm{kg}^{-1}\right)$ & 12 & 12 & 12 & 12 \\
\hline Zinc $\left(\mathrm{mg} \mathrm{kg}^{-1}\right)$ & 3500 & 3500 & 3500 & 3500 \\
\hline Virginiamycin $\left(\mathrm{mg} \mathrm{kg}^{-1}\right)$ & - & 2750 & - & - \\
\hline Lasalocid $\left(\mathrm{mg} \mathrm{kg}^{-1}\right)$ & - & - & 2750 & - \\
\hline Salinomycin $\left(\mathrm{mg} \mathrm{kg}^{-1}\right)$ & - & - & - & 2750 \\
\hline
\end{tabular}

${ }^{1}$ Suplephós 70, Suplementar Nutrição Animal, Dourados, MS, Brazil.

${ }^{2}$ Control $=$ mineral supplement, VIRG $=$ mineral supplement + virginiamycin, LASA $=$ mineral supplement + lasalocid sodium, and SALI $=$ mineral supplement + salinomycin sodium. 
field, homogenized, and two subsamples were taken and sent to the laboratory. In the laboratory, one of the subsamples was placed in paper bags to determine dry matter (DM) and forage dry mass (FDM), and in the other, the manual separation of green leaf, stem (stem + leaf sheath), and dead material (dried and/or dead leaves) was performed to determine the morphological constitution of the plant (Table 2).

Stocking rate (SR) was calculated from the sum of BW of the five animals in each paddock, divided by the weight of one animal unit $(\mathrm{AU}=450 \mathrm{~kg})$ and divided by the paddock area $(2 \mathrm{ha})$. Forage allowance (FA) and green leaf allowance (GLA) were calculated by the following formula: (a/SR)/28, in which $\mathrm{a}=$ total mass for FA or green leaf dry mass for GLA and $28=$ number of days of the experimental period (Table 2).

Forage samples from each paddock were analyzed according to AOAC (2000): DM, method 930.15; organic matter (OM), method 942.05; crude protein (CP), method 976.05; ethereal extract (EE), method 920.39; and ashes, method 942.05. The filter bag technique using a Tecnal unit (TE-149; Tecnal, Piracicaba, SP, Brazil) was employed for neutral detergent fiber (NDF) analysis using $5 \times 5 \mathrm{~cm}$ filter bags with $100-\mu \mathrm{m}$ porosity (non-woven fabric), in which $0.5 \mathrm{~g}$ of forage sample was added and submerged in neutral detergent solution (Van Soest et al., 1991). The NDF was expressed with correction for ashes and protein (NDFap). Non-fibrous carbohydrates (NFC) were calculated according to NRC (2001) as: $\mathrm{NFC}\left(\mathrm{g} \mathrm{kg}^{-1}\right)=1000-\left(\mathrm{g} \mathrm{kg}^{-1} \mathrm{NDFap}+\mathrm{g} \mathrm{kg}^{-1} \mathrm{CP}+\mathrm{g} \mathrm{kg}^{-1} \mathrm{EE}+\mathrm{g} \mathrm{kg}^{-1} \mathrm{MM}\right)$. The chemical composition of marandu grass is described in Table 3.

The ingestive behavior of the animals was evaluated on $\mathrm{d} 21$ of each period, from sunrise to sunset $(6.00$ to $18.00 \mathrm{~h} ; 12 \mathrm{~h})$. The evaluations were carried out by six previously trained evaluators, using binoculars with a 16 -fold increase and annotations performed in 10-minute intervals. The evaluators were divided into two groups with six-hour scales, and each evaluator was positioned in an observation tower located in the center of each block, being responsible for the four paddocks of the block. Grazing, idle, rumination, water drinking, and mineral supplement intake time were measured.

The experimental design used was randomized blocks. Data were analyzed using the PROC MIXED of SAS (Statistical Analysis System, version 9.4) for time-repeated measures, with the evaluation dates (period) being used as a repeating effect, and the compound symmetry covariance structure was selected through the lowest Akaike information criterion. The statistical model used was:

$$
y_{i j k}=\mu+T_{i}+P_{j}+\beta_{k}+(T \times P)_{i j}+\varepsilon_{i j k^{\prime}}
$$

in which $y_{i j k}={ }_{i j k}$ observation, $\mu=$ overall average, $T_{i}=$ treatment effect, $P_{j}=$ period effect, $\beta_{k}=$ block effect, $(T \times P)_{i j}=$ interaction effect between treatment $i$ and period $j$, and $\varepsilon_{i j k}=$ random error. The least

Table 2 - Marandu grass components in the experimental periods

\begin{tabular}{|c|c|c|c|c|}
\hline \multirow{2}{*}{ Item } & \multicolumn{4}{|c|}{ Period $^{1}$} \\
\hline & Day 0 to 28 & Day 28 to 56 & Day 56 to 84 & Day 84 to 112 \\
\hline FDM (kg of DM ha'-1) & 3350 & 4100 & 4250 & 3800 \\
\hline Green leaf ( $\mathrm{g} \mathrm{kg}^{-1}$ of DM) & 571 & 482 & 369 & 305 \\
\hline Stem ( $\mathrm{g} \mathrm{kg}^{-1}$ of DM) & 405 & 470 & 534 & 560 \\
\hline Dead material ( $\mathrm{g} \mathrm{kg}^{-1}$ of DM) & 24 & 48 & 97 & 135 \\
\hline Stocking rate $\left(\mathrm{AU} \mathrm{ha}^{-1}\right)$ & 1.30 & 1.42 & 1.50 & 1.57 \\
\hline FA (kg of DM $100 \mathrm{~kg}^{-1}$ of BW day ${ }^{-1}$ ) & 20.82 & 23.95 & 22.91 & 19.56 \\
\hline GLA (kg of DM $100 \mathrm{~kg}^{-1}$ of BW day ${ }^{-1}$ ) & 12.06 & 11.59 & 8.54 & 5.16 \\
\hline
\end{tabular}

FDM - forage dry mass; DM - dry matter; AU - animal unit; FA - forage allowance; BW - body weight; GLA - green leaf allowance.

${ }^{1}$ The values presented are the average of the results of the initial and final collections of each experimental period. 
Table 3 - Chemical composition of marandu grass in experimental periods

\begin{tabular}{|c|c|c|c|c|}
\hline \multirow{2}{*}{ Item $\left(\mathrm{g} \mathrm{kg}^{-1}\right)$} & \multicolumn{4}{|c|}{ Period $^{1}$} \\
\hline & Day 0 to 28 & Day 28 to 56 & Day 56 to 84 & Day 84 to 112 \\
\hline \multicolumn{5}{|c|}{ Forage dry mass } \\
\hline DM & 227.8 & 260.6 & 291.0 & 339.4 \\
\hline NDFap & 719.4 & 737.8 & 752.3 & 763.7 \\
\hline $\mathrm{ADF}$ & 376.7 & 393.4 & 401.8 & 416.4 \\
\hline $\mathrm{CP}$ & 64.3 & 48.9 & 40.6 & 36.8 \\
\hline $\mathrm{EE}$ & 27.4 & 21.5 & 13.4 & 9.2 \\
\hline Ashes & 74.1 & 65.9 & 60.4 & 57.8 \\
\hline NFC & 114.9 & 125.9 & 133.3 & 132.5 \\
\hline \multicolumn{5}{|l|}{ Stem } \\
\hline $\mathrm{CP}$ & 43.1 & 36.0 & 33.4 & 29.9 \\
\hline NDFap & 764.6 & 789.9 & 792.5 & 791.3 \\
\hline $\mathrm{ADF}$ & 436.0 & 452.6 & 458.2 & 464.2 \\
\hline Ashes & 62.7 & 48.7 & 39.7 & 37.7 \\
\hline \multicolumn{5}{|l|}{ Green leaf } \\
\hline $\mathrm{CP}$ & 79.9 & 64.6 & 62.6 & 67.6 \\
\hline NDFap & 692.0 & 698.0 & 697.2 & 696.9 \\
\hline $\mathrm{ADF}$ & 335.4 & 335.3 & 327.1 & 329.1 \\
\hline Ashes & 61.7 & 59.9 & 57.3 & 59.0 \\
\hline
\end{tabular}

DM - dry matter; NDFap - neutral detergent fiber corrected for ashes and protein; ADF - acid detergent fiber; CP - crude protein; EE - ethereal extract; NFC - non-fibrous carbohydrates $(N F C=1000-($ NDFap + CP + EE + MM), NRC, 2001).

${ }^{1}$ The values presented are the average of the results of the initial and final collections for each experimental period.

squares averages were compared using the Tukey test if a significant F-test was detected. Significance was defined when $\mathrm{P} \leq 0.05$.

\section{Results}

There was no treatment effect on ingestive behavior activities (Table 4). There was a period effect on grazing time and water drinking time. Grazing time was lower during the first period and increased until the fourth. Water drinking time was higher in the first period and lower in the fourth period. Rumination time presented an interaction period $\times$ treatment. In general, the first period did not differ from the second, but it was superior over the third and fourth for all treatments. There were no effects of treatment $\times$ period, treatment, and period for idle time (Table 4).

There was no treatment effect on mineral supplement intake in $\mathrm{g} \mathrm{d}^{-1}$ or $\mathrm{g} \mathrm{kg}^{-1}$ of BW; however, there was a period effect for these variables (Table 5). Mineral supplement intake in $\mathrm{g} \mathrm{d}^{-1}$ was greater in the first three periods compared with the fourth. When the mineral supplement intake was evaluated, in $\mathrm{g} \mathrm{kg}^{-1}$ of BW, it was greater in the first two periods compared with the third and fourth periods. The active ingredient intake presented interaction period $\times$ treatment (Table 5). For this variable, for all treatments, intake was greater in the first period and lower in the fourth. In the first period, the intake of the active ingredient LASA was greater than that of VIRG and SALI, and in the last period, intake of LASA and SALI were greater than that of VIRG.

There was an increase in BW throughout the experimental periods, but there was no effect of the antibiotic growth promoters and nor interaction with the periods (Table 6). The ADG of the animals did not differ among treatments and there was no interaction with the periods, but it decreased throughout the experimental periods for all treatments (Table 6). 
Table 4 - Average time (minutes) spent by Nellore bulls during day time period (6.00 to $18.00 \mathrm{~h}$ ) in grazing, idle, rumination, water drinking, and mineral supplement intake activities

\begin{tabular}{|c|c|c|c|c|c|c|c|c|c|}
\hline \multirow{2}{*}{ Item } & \multicolumn{4}{|c|}{ Treatment $^{1}$} & \multirow{2}{*}{$\begin{array}{c}\text { Average } \\
\text { per period }\end{array}$} & \multirow{2}{*}{ SEM } & \multicolumn{3}{|c|}{ P-value } \\
\hline & Control & VIRG & LASA & SALI & & & Period (P) & Treatment (T) & $\mathrm{P} \times \mathrm{T}$ \\
\hline Grazing time (min) & & & & & & & $<0.0091$ & 0.6417 & 0.0844 \\
\hline Day 0 to 28 & 404.0 & 422.0 & 436.0 & 440.0 & $425.5 \mathrm{C}$ & 15.6 & & & \\
\hline Day 28 to 56 & 517.3 & 520.0 & 486.7 & 448.0 & $493.0 \mathrm{~B}$ & 5.1 & & & \\
\hline Day 56 to 84 & 474.0 & 482.0 & 491.3 & 430.0 & $469.3 \mathrm{BC}$ & 23.8 & & & \\
\hline Day 84 to 112 & 546.0 & 504.7 & 542.0 & 523.3 & $529.0 \mathrm{~A}$ & 7.9 & & & \\
\hline Idle time (min) & 122.3 & 124.0 & 124.5 & 139.0 & - & 5.0 & 0.0883 & 0.1667 & 0.9887 \\
\hline Rumination time (min) & & & & & & & $<0.0001$ & 0.7395 & 0.0482 \\
\hline Day 0 to 28 & 156.7A & $157.3 \mathrm{~A}$ & $140.0 \mathrm{~A}$ & $142.0 \mathrm{~A}$ & - & 22 & & & \\
\hline Day 28 to 56 & $101.3 \mathrm{AB}$ & $76.0 \mathrm{AB}$ & 82.7AB & $91.3 \mathrm{AB}$ & - & 18.7 & & & \\
\hline Day 56 to 84 & $78.0 \mathrm{~B}$ & $65.3 \mathrm{~B}$ & $85.3 \mathrm{~B}$ & $105.3 \mathrm{~B}$ & - & 15.3 & & & \\
\hline Day 84 to 112 & $54.7 \mathrm{~B}$ & $102.7 \mathrm{~B}$ & $80.0 \mathrm{~B}$ & $92.0 \mathrm{~B}$ & - & 14.1 & & & \\
\hline Water drinking time (min) & & & & & & & 0.0009 & 0.7072 & 0.3511 \\
\hline Day 0 to 28 & 16.7 & 22.0 & 21.3 & 14.0 & $18.5 \mathrm{~A}$ & 2.4 & & & \\
\hline Day 28 to 56 & 14.7 & 10.7 & 19.3 & 19.3 & $16.0 \mathrm{AB}$ & 2.4 & & & \\
\hline Day 56 to 84 & 13.3 & 14.0 & 12.7 & 9.3 & $12.3 \mathrm{AB}$ & 2.4 & & & \\
\hline Day 84 to 112 & 6.7 & 17.3 & 3.3 & 7.3 & $8.7 \mathrm{~B}$ & 2.4 & & & \\
\hline $\begin{array}{l}\text { Mineral supplement } \\
\text { intake time (min) }\end{array}$ & 9.3 & 4.6 & 2.3 & 7.2 & - & 1.6 & 0.7412 & 0.0944 & 0.3217 \\
\hline
\end{tabular}

SEM - standard error of the mean.

${ }^{1}$ Control $=$ mineral supplement, VIRG $=$ mineral supplement + virginiamycin, LASA $=$ mineral supplement + lasalocid sodium, and SALI $=$ mineral supplement + salinomycin sodium.

${ }^{2}$ Averages per period are presented only when the P-value for period is $\leq 0.05$ and $\mathrm{T} \times \mathrm{P}>0.05$

Different uppercase letters differ from each other in the columns by Tukey's test $(\mathrm{P} \leq 0.05)$.

Table 5 - Average mineral supplement intake and antibiotic growth promoters for Nellore bulls raised on Marandu grass

\begin{tabular}{|c|c|c|c|c|c|c|c|c|c|}
\hline \multirow{2}{*}{ Item } & \multicolumn{4}{|c|}{ Treatment $^{1}$} & \multirow{2}{*}{$\begin{array}{c}\text { Average } \\
\text { per period }\end{array}$} & \multirow{2}{*}{ SEM } & \multicolumn{3}{|c|}{ P-value } \\
\hline & Control & VIRG & LASA & SALI & & & Period (P) & Treatment (T) & $\mathrm{P} \times \mathrm{T}$ \\
\hline \multicolumn{7}{|c|}{ Mineral supplement intake (g animal ${ }^{-1}$ day $^{-1}$ ) } & $<0.0001$ & 0.3585 & 0.7585 \\
\hline Day 0 to 28 & 107.19 & 99.08 & 144.76 & 115.88 & $116.73 \mathrm{~A}$ & 9.09 & & & \\
\hline Day 28 to 56 & 96.71 & 90.36 & 133.00 & 122.29 & $110.59 \mathrm{~A}$ & 9.09 & & & \\
\hline Day 56 to 84 & 99.31 & 70.99 & 108.82 & 110.21 & $97.33 \mathrm{~A}$ & 9.09 & & & \\
\hline Day 84 to 112 & 51.98 & 40.57 & 66.62 & 56.00 & $53.79 \mathrm{~B}$ & 9.09 & & & \\
\hline \multicolumn{7}{|c|}{ Mineral supplement intake $\left(\mathrm{g} \mathrm{kg}^{-1}\right.$ of $\left.\mathrm{BW}\right)$} & $<0.0001$ & 0.3368 & 0.7118 \\
\hline Day 0 to 28 & 0.46 & 0.42 & 0.62 & 0.49 & $0.50 \mathrm{~A}$ & 0.03 & & & \\
\hline Day 28 to 56 & 0.38 & 0.35 & 0.52 & 0.48 & $0.43 \mathrm{~A}$ & 0.03 & & & \\
\hline Day 56 to 84 & 0.37 & 0.26 & 0.40 & 0.40 & $0.36 \mathrm{~B}$ & 0.03 & & & \\
\hline Day 84 to 112 & 0.18 & 0.14 & 0.24 & 0.20 & $0.19 \mathrm{C}$ & 0.03 & & & \\
\hline \multicolumn{7}{|c|}{ Active ingredient intake $\left(\mathrm{mg} \mathrm{kg}^{-1}\right.$ of BW) } & $<0.0001$ & 0.0003 & 0.0006 \\
\hline Day 0 to 28 & - & $1.17 \mathrm{Ab}$ & $1.69 \mathrm{Aa}$ & $1.36 \mathrm{Ab}$ & - & 0.03 & & & \\
\hline Day 28 to 56 & - & $0.97 \mathrm{ABa}$ & $1.43 \mathrm{Aa}$ & $1.31 \mathrm{Aa}$ & - & 0.08 & & & \\
\hline Day 56 to 84 & - & $0.73 \mathrm{BCa}$ & $1.11 \mathrm{Ba}$ & $1.11 \mathrm{Aa}$ & - & 0.08 & & & \\
\hline Day 84 to 112 & - & $0.39 \mathrm{Cb}$ & $0.66 \mathrm{Ca}$ & $0.54 \mathrm{Ba}$ & - & 0.02 & & & \\
\hline
\end{tabular}

BW - body weight; SEM - standard error of the mean.

${ }^{1}$ Control $=$ mineral supplement, VIRG $=$ mineral supplement + virginiamycin, LASA $=$ mineral supplement + lasalocid sodium, and SALI $=$ mineral supplement + salinomycin sodium.

${ }^{2}$ Averages per period are presented only when the $\mathrm{P}$-value for period is $\leq 0.05$ and $\mathrm{T} \times \mathrm{P}>0.05$

Different uppercase letters differ from each other in the columns and different lowercase letters differ from each other in the rows by Tukey's test $(\mathrm{P} \leq 0.05)$. 
Table 6 - Average body weight and average daily gain of Nellore bulls raised on Marandu grass and receiving mineral supplementation with antibiotic growth promoters

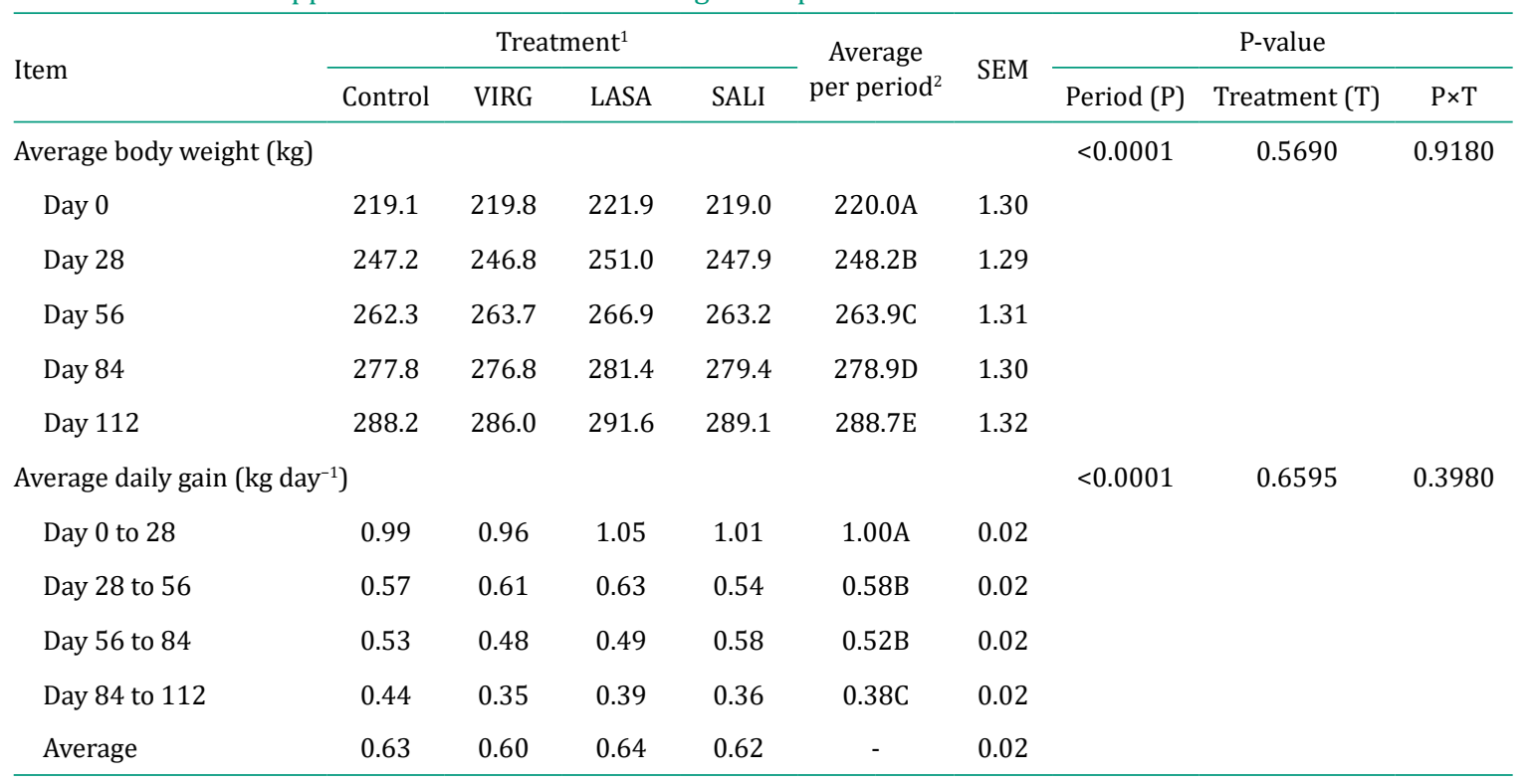

SEM - standard error of the mean.

${ }^{1}$ Control $=$ mineral supplement, VIRG $=$ mineral supplement + virginiamycin, LASA $=$ mineral supplement + lasalocid sodium, and SALI $=$ mineral supplement + salinomycin sodium

${ }^{2}$ Averages per period are presented only when the P-value for period is $\leq 0.05$ and $\mathrm{T} \times \mathrm{P}>0.05$

Different uppercase letters differ from each other in the columns by Tukey's test $(\mathrm{P}<0.05)$.

\section{Discussion}

The time bulls spent on daily activities is in line with the frequency observed for grazing cattle, as they spent 90 to $95 \%$ of the time in grazing, rumination, and idle activities (Kilgour et al., 2012). There was an increase in grazing time throughout the experimental periods, which coincided with the decrease in GLA and a decrease in the nutritional quality of the pasture, indicating that a longer grazing time was required to meet nutritional requirements. The average time used by the animals in grazing activity was $7.98 \mathrm{~h}$, exactly the same time observed for crossbred steers kept in marandu grass pasture, consuming $2 \mathrm{~g} \mathrm{~kg}^{-1}$ of BW of concentrate supplement in a tropical climate during the rainy season (Mendes et al., 2015).

The rumination time found by Mendes et al. (2015) was $7.52 \mathrm{~h}$ and, according to review study by Kilgour (2012) for beef cattle, it ranged from 4.7 to $10.2 \mathrm{~h}$. These results were much higher than those found in this study, which was less than $2 \mathrm{~h}$. These same authors mentioned that a great part of this activity is done in the nocturnal period and, since the ingestive behavior in this study was evaluated only during the diurnal period, it justifies the low average time observed for this activity. The shortest water drinking time, in the fourth period compared with the first, is related to the decrease in minimum temperature (NRC, 1996) at the end of the experiment.

The mineral supplement intake was not reduced when associated with antibiotic growth promoters. The literature mentions that the addition of salinomycin to free-choice mineral supplement for steers reduced the intake of mineral by half compared with the control group (131 and $65 \mathrm{~g} \mathrm{~d}^{-1}$, mineral supplement and mineral supplement + salinomycin, respectively; Bagley et al., 1988). Furthermore, the addition of lasalocid to free-choice mineral supplement for heifers showed similar mineral intake as the control group in two consecutive years (83.2 and 89.1, 140.3 and $147.2 \mathrm{~g} \mathrm{~d}^{-1}$, mineral supplement and mineral supplement + lasalocid, year 1 and 2, respectively; Rode et al., 1994).

Throughout the experimental periods, there was a reduction in mineral supplementation intake $\left(\mathrm{g} \mathrm{d}^{-1}\right.$

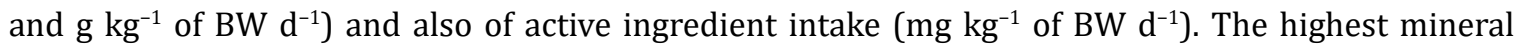


supplementation intake occurs with a great allowance of forage mass and high nutritional quality (Rode et al., 1994), and the decrease in the nutritional quality of the pasture, due to the lower proportion of green leaf:stem, led to a decrease in the mineral supplement intake.

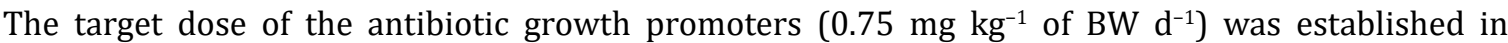
accordance with a meta-analysis performed by Bretschneider et al. (2008), who demonstrated that the antibiotic growth promoters used have dose-dependent results with quadratic behavior and an optimum performance point between 0.75 and $1 \mathrm{mg} \mathrm{kg}^{-1}$ of BW d-1 $\mathrm{d}^{-1}$. Although the active ingredient intake was higher than expected, with the exception of the LASA supplement, the average daily dose was close to the maximum response point (Bretschneider et al., 2008). However, positive effects of lasalocid sodium on ADG (0.6 and $0.7 \mathrm{~kg} \mathrm{~d}^{-1}$ for control and lasalocid, respectively) were obtained during the grazing period with bulls receiving $250 \mathrm{mg}$ per animal $\left(1.2 \mathrm{mg} \mathrm{kg}^{-1}\right.$ of BW d $\left.\mathrm{d}^{-1}\right)$ incorporated into $1 \mathrm{~kg}$ of beet sugar (Boucque et al., 1988).

The absence of effect of the antibiotic growth promoters added to the mineral supplement on growth performance in this study opposes the findings of Bretschneider et al. (2008) and Golder and Lean (2016). In a meta-analysis, Golder and Lean (2016) found that the use of lasalocid by cattle, both confined or grazing, increased the ADG $\left(40 \mathrm{~g} \mathrm{~d}^{-1}\right)$ without affecting DM intake. In another meta-analysis, Bretschneider et al. (2008) evaluated the effect of antibiotic growth promoters exclusively for grazing beef cattle and observed increase on ADG with virginiamycin supply in $13.1 \%$ ( 0.61 and $0.69 \mathrm{~kg} \mathrm{~d}^{-1}$ for control and virginiamycin, respectively), lasalocid in $10.3 \%$ ( 0.78 and $0.86 \mathrm{~kg} \mathrm{~d}^{-1}$ for control and lasalocid, respectively), and salinomycin in $37.5 \%$ ( 0.48 and $0.66 \mathrm{~kg} \mathrm{~d}^{-1}$ for control and salinomycin, respectively). These results are explained by changes in ruminal metabolism, such as the lower concentration of acetate, higher propionate rate, and improved efficiency of rumen nitrogen use, measured as the flow of non-ammonia nitrogen compounds into the small intestine (Salinas-Chavira et al., 2009). It is noteworthy that most of the meta-analysis studies used the concentrated supplement as a vehicle for growth promoters, which differs from this study.

The lack of effects of growth promoters on BW and ADG can be explained by the great variability in the daily voluntary intake of mineral supplementation by grazing cattle (Manzano et al., 2012), since the responses depend on a consistent daily intake (Rode et al., 1994). Manzano et al. (2012) compared the feeding behavior and free-choice mineral supplement intake, offered ad libitum to grazing steers throughout the year seasons spring-summer and autumn and did not observe similarity between seasons ( $96.6 \mathrm{vs.} 85.4 \mathrm{~g} \mathrm{~d}^{-1}$ for spring-summer and autumn, respectively) but found differences among animals, days, and periods. Individual intake was different between animals ranging from 0 to $400 \mathrm{~g} \mathrm{~d}^{-1}$ in spring-summer for 0 to $440 \mathrm{~g} \mathrm{~d}^{-1}$ in autumn. The inclusion of $\mathrm{NaCl}\left(261.5 \mathrm{~g} \mathrm{~kg}^{-1}\right)$ was very similar to that used in this study $\left(277 \mathrm{~g} \mathrm{~kg}^{-1}\right)$.

The free access of cattle to the powdered mineral supplement has been shown to be of interest for meeting mineral requirements, but not as a vehicle for antibiotic growth promoter additives. The absence of consumption, under-consumption, or over-consumption may compromise the effectiveness of the active ingredient.

\section{Conclusions}

The free-choice mineral supplementation intake of bulls has a high variability and hampers the regulation of the intake of antibiotic growth promoter additives. The use of mineral supplements as a growth promoter vehicle does not affect ingestive behavior, mineral intake, and growth performance of grazing bulls, and this can lead to waste and increasing costs in cattle production.

\section{Conflict of Interest}

The authors declare no conflict of interest.

R. Bras. Zootec., 48:e20190114, 2019 


\section{Author Contributions}

Conceptualization: G.L. Franco. Methodology: G.L. Franco. Project administration: J.M.S. Diogo and G.L. Franco. Supervision: J.M.S. Diogo, M.C. D’Oliveira and C.J. Silva. Visualization: J.M.S. Diogo, C.Q. Mendes and S.L.S. Cabral Filho. Writing-original draft: J.A.M. Beltrame. Writing-review \& editing: M. Vedovatto.

\section{Acknowledgments}

The authors are thankful to the Conselho Nacional de Desenvolvimento Científico e Tecnológico (CNPq), for granting the financial support for this study (grant number 486499/2012-0).

\section{References}

AOAC - Association of Official Analytical Chemists. 2000. Official methods of analysis. 17th ed. AOAC International, Gaithersburg, MD.

Bagley, C. P.; Feazel, J. I.; Morrison, D. G. and Lucas, D. M. 1988. Effects of salinomycin on ruminal characteristics and performance of grazing beef steers. Journal of Animal Science 66:792-797. https://doi.org/10.2527/jas1988.663792x

Boucque, C. V.; Fiems, L. O.; Cottyn, B. G. and Buysse, F. X. 1988. Long-term supplementation of lasalocida-sodium for beef bulls during grazing and subsequent finishing period. Archives of Animal Nutrition 11:995-1003.

Bretschneider, G.; Elizalde, J. C. and Pérez, F. A. 2008. The effect of feeding antibiotic growth promoters on the performance of beef cattle consuming forage-based diets: A review. Livestock Science 114:135-149. https://doi. org/10.1016/j.livsci.2007.12.017

EMBRAPA - Empresa Brasileira de Pesquisa Agropecuária. 1999. Sistema brasileiro de classificação de solos. 1.ed. Rio de Janeiro.

Golder, H. M. and Lean, I. J. 2016. A meta-analysis of lasalocid effects on rumen measures, beef and dairy performance, and carcass traits in cattle. Journal of Animal Science 94:306-326. https://doi.org/10.2527/jas.2015-9694

Kilgour, R. J. 2012. In pursuit of "normal": A review of the behaviour of cattle at pasture. Applied Animal Behaviour Science 138:1-11. https://doi.org/10.1016/j.applanim.2011.12.002

Kilgour, R. J.; Uetake, K.; Ishiwata, T. and Melville, G. J. 2012. The behaviour of beef cattle at pasture. Applied Animal Behaviour Science 138:12-17. https://doi.org/10.1016/j.applanim.2011.12.001

Manzano, R. P.; Paterson, J.; Harbac, M. M. and Lima Filho, R. 0. 2012. The effect of season on supplemental mineral intake and behavior by grazing steers. The Professional Animal Scientist 28:73-81. https://doi.org/10.15232/ S1080-7446(15)30317-X

Mendes, F. B. L.; Silva, R. R.; Carvalho, G. G. P.; Silva, F. F.; Lins, T. O. J. D.; Silva, A. L. N.; Macedo, V.; Abreu Filho, G.; Souza, S. O. and Guimarães, J. O. 2015. Ingestive behavior of grazing steers fed increasing levels of concentrate supplementation with different crude protein contents. Tropical Animal Health and Production 47:423-428. https://doi.org/10.1007/s11250-014-0741-z

NRC - National Research Council. 1996. Nutrient requirements of beef cattle. 7th rev. ed. National Academy Press, Washington, DC.

NRC - National Research Council. 2001. Nutrient requirements of dairy cattle. 7th rev. ed. National Academy Press, Washington, DC.

Page, S. W. 2003. The role of enteric antibiotics in livestock production. 1st ed. Avcare, Canberra.

Rode, L. M.; Lysyk, T. J. and Beauchemin, K. A. 1994. Intake of lasalocida-containing mineral supplements by grazing beef heifers. Canadian Journal of Animal Science 74:77-82.

Russel, J. B. and Strobel, H. J. 1989. Effect of ionophores on ruminal fermentation. Applied and Environmental Microbiology 55:1-6.

Salinas-Chavira, J.; Lenin, J.; Ponce, E.; Sanchez, U.; Torrentera, N. and Zinn, R. A. 2009. Comparative effects of virginiamycin supplementation on characteristics of growth-performance, dietary energetics, and digestion of calf-fed Holstein steers. Journal of Animal Science 87:4101-4108. https://doi.org/10.2527/jas.2009-1959

Van Soest, P. J.; Robertson, J. B. and Lewis, B. A. 1991. Symposium: carbohydrate methodology, metabolism, and nutritional implications in dairy cattle. Journal of Dairy Science 74:3583-3597. 